\title{
CRITICAL FACTORS RESPONSIBLE FOR FAILURE OF CONSTRUCTION PROJECT IN KOLKATA: AN EMPIRICAL STUDY
}

\author{
ARIJIT MAITY \\ Research Scholar, Department-Commerce, college name-University of Calcutta, \\ University name- University of Calcutta, location / place- KOLKATA
}

\begin{abstract}
Priority should be given to the rapidly changing construction industry in India in order to meet the challenges associated with the infrastructure projects management. This study has been performed for identifying the factors that are accountable for failures in the construction industry.

This study is focused on finding the responsible factors for any project failure. Initially, with the sample size of 10, exploratory research was performed, which included individual house builders, engineers, contractors, masons, builders, and dealers to get the essence of the issue.

For collecting the primary data, the research instrument that was used was the questionnaire. The questionnaire that was prepared with the sample size of 10 was further amended and managed with the sample size of 200 respondents in Kolkata. Civil engineers, surveyors, architects and building engineers were selected as target respondents, who are found to be experienced in the infrastructure projects management in Kolkata.

To summarise the major factors, factory analysis was performed using SPSS software, which would have an impact on project failure. Summarizing the efforts, exploring the major factors for construction project failure is the first part involved. The second and third parts involved data analysis, research design and major elucidation of the results from the questionnaire that was provided to the respondents. Research findings analysis is also involved.

The inferences, implications and limitations of this research were shown and a general conclusion was obtained. KEYWORDS: Factor Analysis, Failure, Factors, Project, Management \& Kolkata
\end{abstract}

Received: Nov 08, 2017; Accepted: Nov 28, 2017; Published: Dec 06, 2017; Paper Id.: IJMMSEDEC20172

\section{INTRODUCTION}

\section{A Brief Overview of Kolkata Construction Industry}

The construction industry directly and indirectly contributes majorly towards the GDP of India. This industry includes 33 million people. Therefore, any changes made in the construction sector, will definitely affect the associated industries such as steel, skill-enhancement, cement, technology, etc.

This industry shows positive signs, though the activities appear to be quite slow as of now. Prolonged slowdown of real estate market has resulted in unsold housing projects throughout India.

Concurrently, this sector is spinning with skilled workforce shortage severely. In many other parts of the country, shortage of raw materials, sand and political disturbances also act as growth limitations. However, the Indian construction sector pace on the ground does not show what is available in store for the future. For instance, there will be increase in the potential and pace of this industry with the technological advancements that also acts as 
a growth catalyst. The generation of employment across a variety of skill sets is one among its positive influences. Introduction of new technology into India and the international infrastructure players' entry is also one of the reasons for employment generation.

Alongside the Smart Cities project, the Government's 'Housing for All by 2022' acts as a major changer of game for the industry. An increase in the construction activity is resulted from the increased trigger for creating the housing mission, which is accompanied by the faster approvals and other policy changes, which results in the increase of construction activity. Similarly, increased activity in infrastructure and associated sectors are brought in by the Atal Mission for Rejuvenation and Urban Transformation (AMRUT).

FDI norms have been eased in 15 sectors including construction development and real estate, which shows positive implications and the larger economy. Tax-related complexities are eased by the introduction of GST in the construction sector and it has brought a major spurt in its growth and activity.

In the immediate future, infrastructure and township house have also become the major drivers for the construction sector. In most of the cases, the townships development and their related infrastructure occur in the city corridors, and a lot of support is extended by the Government for the development of untapped areas.

For Indian construction sector, better times lie ahead. The events witnessed now are during the buffer period, in which various growth drivers and policy changes are still being loaded into the system. We will find a renewed vibrancy and growth within a matter of time.

Lot of projects were either re-negotiated or abandoned with lot of contracts facing problems with payment and due to lack of financial assistance and guarantees. In addition to this, government emphasis has moved from complex construction projects to basic building projects. There were concerns about the technical proficiency and joint project partnerships between multinational and local companies, which added pressure on the Kolkata private sector that had to get more involved in these projects.

New urban cities were developed with a friendly business environment. To summarize, it is found that the construction industry of Kolkata is growing and has showed its influence on the country's GDP on a large scale.

This research paper has been divided into five sections. The first section provides a brief background on the research issues. The second section provides a literature review on the existing literature to bring the study to a proper perspective. This section is followed by methodology in which the techniques and the measures are detailed in order to achieve the objectives. This paper will also talk about the analysis and the results that arrive from the analysis, before the conclusion and the recommendations are presented at the discussion end.

\section{BACKGROUND OF THE STUDY}

Over the past decades, the contribution to the Kolkata economy by the construction industry is unprecedented. Based on the evidence, it is observed that the projects fail mostly due to the combination of over-budgeting, underbudgeting, schedule overruns, not meeting the requirements of users and improper scope. There are multiple studies that have identified many factors that are responsible for project success. But, there was less focus on the failure of the projects, particularly when it comes to Kolkata construction industry. This study has attempted to fill the gaps by identifying and categorizing the project failures causes in Kolkata by developing a framework from the clients' perspectives, contractors 
and consultants. Factor analysis has been used for achieving the classification of the factors, which establishes the structures associated with failure factors. The major causes of project failures are provided by this insight from the perspective of all the stakeholders involved. By doing so, this will examine and validate the existing assertion or statements, which express an opinion or judgement on the project failures concept in the context of construction industry in Kolkata.

\section{RESEARCH OBJECTIVE}

The main objective of this study is to identify and categorize the project failure causes in the construction industry of Kolkata. The specific goals are as follows:

- Identify the serious failure factors that affect the performance of infrastructure project in Kolkata.

- Using factor analysis, categorise these factors into the factors cluster.

- Degree of agreement on the project failure factors' ranking is tested.

\section{LITERATURE REVIEW}

\section{Past Empirical Studies on Project Failures}

According to Avot (1969), the major causes for failure of projects are wrong selection of project manager, unsupportive top management and unplanned termination of projects.

However, the researchers have recognized project failures in construction at the project level, rather than at the level of company. It has been observed that the reasons for the construction project failure remained the same over a long time period (Morris and Hough, 1987; Abidali and Harris, 1995; Hall, 1982; Russel and Jaselski, 1992).

According to Frederikslust(1978), the success of a project can be defined as the extent to which the objectives and the goals of a project are satisfied. Whenever the objectives and goals of a project have not been met, then it is considered as the project failure. A project is also considered as a failure when the expectation to meet the tripartite criteria of time has been failed to meet, and when the quality and budget are overrun. Recent studies have identified few other reasons such as stakeholder management, sustainability, risk management problems and communication.

Kangari (1988) says that in the construction industry, the client is subjected to bear the financial risk at greater extent for a longer time period, while the contractor is at more risk than the counterpart in any other field.

According to Hughes (1986), the reasons for projects failure are related to irrelevant basic managerial principles such as incorrect action, no proper focus on the management system and due to lack of proper communication of objectives.

Pinto and Mantel (1990) says that it is quite difficult to define why a project fails.

Project failure in smaller companies is small and they are with regard to their owned resources. Project failure among the large companies, including the construction firms have also been identified (Sanvido et al., 1992).

Shortages have been reported in the supply of surveyors, engineers, equipment operators and the skilled workers hinder the stakeholders' ability to handle the higher volumes of work with expected quality workmanship (Materu, 2000;Datta, 2000;Belassi and Tukel, 1996). 
Three important classifications of problems working against the success of projects have been identified by Ogunlana, Promkuntong and Vithool (1996). There are problems related to consultants and clients, issues with inadequacies and shortages in the infrastructure of industry, and the challenges related to incompetent contractor. It is found that these have considerable impact on the performance of projects.

An investigation was conducted by Kaming et al. (1997) in Indonesia on the 31 high-rise projects and found that the time and the cost overruns are the most critical reasons for project failure.

The severity has also been found due to cost overruns rather than the time overruns. The study also mentioned the increase in the material cost due to inflation, inaccurate estimation for materials, and also the complexity, which are the factors causing cost overruns. The time overruns are driven by the sub-factors such as poor labour productivity, design changes, resource shortages and inadequate planning.

According to Chitkara (1998), the primary reasons for failure of projects are improper projects management and inadequate formulation of projects.

A study was conducted by Clough and Sears (2000) and they have found that the construction industry ranks second in the rate of business failure, whereas the restaurants rank first.

Bonnal et al. (2002) says that the skills sets required to manage the project phase and pre-project phase are quite different. Inability in management leads to incorrect personnel selection for project and pre-project phases, which obviously leads to project failure. The studies have also found the factors that are responsible for cost overrun, schedule overrun and so on, in various regions of the world.

Many other reasons for failures have been reportedd by Hughes, Tipett and Thomas (2004), which includes inadequate management of projects, technological failures and improper communication. Some of the other reasons include lack of understanding on project complexity and scope. When the project management principles are implemented successfully, the projects are also succeeded in terms of cost, time, quality and user requirements.

According to the Project Management Book of Knowledge by Project Management Institute (2004), a project's success or failure is measured by the difference in the expectation on a project before and after its completion and also based on the actual performance observed when the project is put into place. The project is considered as a failure when the client and other stakeholders' expectation in terms of schedule, cost and quality is not met by the actual schedule, cost and quality of construction by the contractors and other project teams. Over the years, the search for factors affecting the failure or success of a construction project has attracted the scholars and many practitioners. The reason for this is because of the ability to develop the factors for project failure, could help the contractors and the project teams to evaluate their projects systematically. In literature, several studies were found, which identifies the factors responsible for infrastructure project failures. The below gives a study summary to establish the framework theoretically to test the theory in an empirical way.

Nguyen, Ogunlana and Lan (2004) conducted a study in the developing countries on the large construction projects. The top ranking failure factors/ranking problems were classified into four major categories: poor change management and estimation, incompetent contractors and designers, technological and social issues, and improper tools and techniques. 
Assaf and Al-Hejji (2006) used the questionnaire survey with the Saudi Arabian construction industry context to find the major reasons for the delay among the available 73 different reasons for delay. This was done using the data gathered from consultants, clients and contractors in Saudi Arabia. With this study, it has been found that the most common reason for the delay is the change orders and nearly $70 \%$ of the projects had consumed more time than planned.

Similarly, Sambasivan and Soon (2007) found 28 factors that act as the reason for project failure. These delay factors were classified into contractor-related, material-related, client-related, equipment-related, labour-related, consultant-related, and other external factors.

According to Sweis et al. (2008) and Alaghbari et al. (2007), the financial-related factors also act as the reasons for failure of projects in terms of delay. When the construction cost increases during construction than planned, it leads to delay in receiving payment and obviously it causes the suppliers and sub-contractors to undergo financial difficulties due to interruption in the mechanisms of cash flow subsequently.

Using the tools like interviews and surveys, Toor and Ogunlana (2008) studied the issues leading to project failures due to delays in Thailand. The top rated factors were poor contractor management, lack of resources and labour shortage. Few other factors have also been identified such as deficiencies in scheduling and planning, design delays, order changes and the financial difficulties of a contractor.

Ebeid (2009) says that the causes for project failure are shortage of skilled people and professionals at all the management levels and field operations amongst contractors, clients and consultants in the infrastructure industry. According to Ebeid (2009), some other reasons include lack of strong financial director, lack of engineering skills, and inadequacy in cash flow plan, poor budgetary control and defects in the bidding system.

30 taxonomic variables have been extracted for studies on project failures by Clough and Sears, 2000; Ogunlana, Promkuntong and Vithool, 1996; Kazaz, Ulubeyli and Tuncbilekli, 2012; Assaf and Al-Hejji, 2006; and Sambasivan and soon, 2007. They do not show the entire inventory of factors that contribute to the project, but they show the mostly cited factors.

Chan and Kumaraswamy(1997), Mansfeild et al.(1994), and Jha (2004) cited 14 major factors for project failure. Jha (2004) conducted a study to a) find the critical factors that contribute to the failure and success of projects, (b) estimate the impact on the performance of the projects by the critical success factor. The project's performance was also measured based on the four performance criteria - (1) adherence to the cost (2) adherence to the schedule, (3) dispute performance, and (4) adherence to the quality performance.

The study by Kazaz, Ulubeyli and Tuncbilekli (2012) identified the reasons and causes of delays using the questionnaire survey and identified failures in the infrastructure projects in Turkey. From the survey, three most important factors were found among the 34 factors, which acted as the major causes. They are changes in design and material, payment delays and difficulties in the cash flow by contractors.

From the literature, the commonly known factors of project failure have been summarised below:

- $\quad$ Conflicting Project Objective (CPO)

- $\quad$ Poor Human Resource Management (PHRM)and labour strike 
- $\quad$ Lack of Team Work (LOTW)among stake holders

- Inadequate Project Formulation (IPF)in the beginning

- Very Low Level of Productivity (VLLP)

- $\quad$ Price Fluctuations (PF)

- $\quad$ Project Schedule Delays(PSD)

- $\quad$ Shortage of Materials (SOM)

- Inadequate Technical manpower(ITM)

- Frequent changes user requirements and in design (Many change request- variation of work)(FCD)

- $\quad$ Poor Communication Management (PCM)

- $\quad$ Dishonesty, Corruption and Fraud(DCF)

- Wrong Selection of Project Team (WSPT)

- $\quad$ Lack of efficient change management(LOECM)

- Government interference and overregulation(GIO)

- Improper Planning(IP)

- Natural disaster(ND)

- Vested Interest of Client (VIOC) representative in not getting the completed project on time.

- Culture or Ethnic Misalignment(COEM)

- Inadequate finances(IF), i.e., Cash Flow difficulties

- Hostile Political, Economic and Social environment(HPES)

- $\quad$ Aggressive Competition at Tender Stage (ACTS)

- $\quad$ Slump in Economy(SIE)

- Harsh Climatic Condition at Site (HCCS)

- $\quad$ Poor Quality of Briefing Process (PQBP)

- Urgency emphasised by the owner (UEO) while supplying tender

- Reluctance in Timely Decision by top Management (RTDM) and holding key decision in abeyance

- Uniqueness of the Project Activities (UOPA) requiring high technical knowledge.

- The Capability of Project (COPP) participants to advertise the products to the intended customers

- Unforeseen Ground Condition (UGC) and site conditions changes 
The above mentioned factors are perceived to the reasons for project failures and delays. However, from the review studies, it is apparent that the factors contributing the failure of projects in Kolkata is less covered relatively. Therefore, this study has been conducted to fill in the knowledge gap. In the next section, the methodology used to conduct the research is described.

\section{METHODOLOGY}

The literature review above gives the basics for the development of the research framework on theoretical basis. With the aid of project management literature, case studies, interviews with experts in the industry, a total of 30 attributes affecting the objectives of project performance were identified. A pilot study was performed through interviews with industry experts and academic experts to increase the questionnaire's content validity before the final list of 30 variables was accepted for study.

The main instrument for data collection is the two-part written questionnaire. Part one requires common information about the features of the respondents, such as their academic qualification, organisations classes, and years of experience. Part two requires the respondents to rate the contribution of the 30 factors for project failure in Kolkata construction projects using a scale from $1-5$, where $5=$ strongly agree, $4=$ agree, $3=$ neutral, $2=$ disagree, and $1=$ strongly disagree. After analysis, to identify the factors for project failure, an average scale of 3 was used.

The targeted respondents were architects, engineers, quantity surveyors, and few other professionals those who have handled the projects on construction for consultants, clients and contractors in Kolkata.

Studies showed that the most critical failure factor was the poor risk management in infrastructure projects, while over-budget and management's poor communication ranked second and third. For factor analysis, eight additional components were taken from the 24 items. Risk challenges, project management deficiencies and government interference are taken from the extracted factors. Among others, recommendations show that the project management frameworks should be re-designed to guide the stakeholders to decrease the unexpected risk exposure. Data analysis was done using both inferential statistical tools and descriptive tools. The descriptive tools used are tables, percentages, standard and mean deviation. In this research, the extraction of principal factor was conducted using SPSS on 30 items that were identified as the factors for project failure for a sample of 67 responses. RII (Relative Importance Index) was used to order the opinion of comparative importance attached to the recognized variables of project failure. According to Enshassi, Mohamed and Abushaban, 2009, it was computed as:

$$
\mathrm{RII}=\Sigma \mathrm{W} / \mathrm{A} * \mathrm{~N}
$$

Where, $\mathrm{W}$ is the weight given by the respondents to each variable and ranges from 1 to $5 ; \mathrm{N}$ is the total number of respondents (67) and $\mathrm{A}$ is the highest weight $=5$.

\section{RESULTS AND DISCUSSIONS}

\section{Demographic Survey of Respondents}

The personal traits of 67 respondents have been analysed in this section, who returned valid questionnaires. The analysis result is shown in Table 1. 
Table 1: Demographic Survey of Respondents

\begin{tabular}{llcc}
\hline Variables & Category & Frequency & $\%$ \\
\hline Professional qualification & Civil engineer & 18 & 26.9 \\
& Architect & 19 & 28.4 \\
& Quantity surveyor & 19 & 28.4 \\
& Building engineer & 11 & 16.4 \\
\hline & Total & 67 & 100 \\
\hline Type of projects & Government projects & 37 & 55.2 \\
& Commercial projects & 30 & 44.9 \\
\hline & Total & 67 & 100 \\
\hline Academic qualification & PhD & - & - \\
& MSc/MEng & 21 & 31.3 \\
& BSc/BEng & 46 & 68.7 \\
\hline & Total & 67 & 100 \\
\hline Years of experience & $5-10$ & 8 & 11.9 \\
& $10-20$ & 35 & 52.2 \\
& $20-30$ & 24 & 35.8 \\
& Above 30 & - & - \\
\hline Type of organisation & Total & 67 & 100 \\
\hline & Client & 16 & 23.9 \\
& Consultant & 29 & 43.3 \\
& Contractor & 22 & 32.8 \\
\hline & Total & 67 & 100 \\
\hline
\end{tabular}

Amongst the respondents, there were 19 architects, 11 building engineers, 18 civil engineers, and 19 quantity surveyors. Among them, 37 respondents have identified to have handled government projects, whereas 30 of them have experience working with commercial projects. Among them, 21 respondents have been found have to master degrees or the equivalent, whereas 67 of them are found to have bachelor degrees or the equivalent. When classified in terms of experience, 24 of them had 20-30 years of experience, 35 had 10-20 years of experience, and only eight had 5-10 years of experience. No one of them fall under the category of 30 years of experience. Among these respondents, 29 work for consultant agencies, 16 works for client organisations, whereas 22 work for contractors. The results show a sensibly widen respondents in terms of the normal alignment used for the research. Hence, their opinions and views are deemed a dependable sample of the industry.

\section{Preliminary Investigation}

Three tests were conducted to ensure that the study constructs meet the necessary pattern for analysis. They are validity, reliability and normality checks. Cronbach's alpha $(\alpha)$ was calculated to demonstrate the items reliability in the questionnaire and to examine the scales' internal consistency. Pallant (2004) says that a threshold of 0.7 is believed to be sufficient for analysis. For 30 items, a Cronbach's alpha $(\alpha)$ of 0.704 was calculated, which is more than the suggested threshold value of 0.7 , validating the study constructs' reliability. Content validity makes sure that questions or contents in the survey measure the topic being investigated. This was done based on a thorough literature review and crossexamination of contents by two $\mathrm{PhD}$ students and two academic researchers. Their observations and subsequent adjustments of the contents in the questionnaire ensured that they had validity of content. Finally, regularity of the 30 variables was checked using tests for kurtosis and skewness. According to Chan, Ho and Tam (2001), the observed values of kurtosis and skewness must be examined against the null hypothesis of zero as the values of kurtosis and skewness are zero when a distribution is normal. As shown in table 2 , the values were within the range of -2.575 to +2.575 ( $\mathrm{p}<0.01$, 
two tailed test). Therefore, they are seen to be normally distributed, reasonably.

\section{Identification of Project Failure Factors for Infrastructure Projects in Kolkata}

From the literature, a list of 30 factors was adapted and subjected to the respondents' views. They responses were rated using a 5-point Likert scale: 5 = strongly agree, 4 = agree, $3=$ somehow agree, $2=$ disagree, and $1=$ strongly disagree. The analysis outcome from SPSS is shown in Table 2. The end result shows that "poor risk management" ranks first, with a mean index of 4.52. This is followed by "budget overrun" ranking second with a mean index of 4.49, while "poor communication management" ranks third, with a mean index of 4.45. When the top 10 ranked factors were analyzed, the results showed that there was only a minor variation in the significance attached to the factors related to each other. For example, there was a $90.1 \%$ significance attached to budget overrun and $90.4 \%$ significance rating attached to poor risk management, which is a minor variation in importance of only $0.3 \%$.

Table 2: Result of Analysis for Project Failure Factors of Infrastructure Projects in SA

\begin{tabular}{|c|c|c|c|c|c|c|c|}
\hline Variables & Min & Max & Mean & SD & Skewness & Kurtosis & Rank \\
\hline CONOBJECTIV & 1 & 5 & 3.07 & 0.91 & 0.098 & -1.44 & 21 \\
\hline LAKOFTMWK & 2 & 5 & 3.57 & 0.7 & 0.026 & -0.179 & 10 \\
\hline INEXPEOFPM & 1 & 5 & 3.27 & 0.83 & -0.378 & 0.573 & 17 \\
\hline POORMOTIV & 1 & 4 & 2.54 & 0.75 & 0.095 & -0.263 & 23 \\
\hline LACKOFUSER & 1 & 5 & 3.22 & 0.9 & -0.592 & 0.013 & 18 \\
\hline BUDGOVERUN & 4 & 5 & 4.49 & 0.5 & 0.031 & -2.062 & 2 \\
\hline SCHEDELAYS & 3 & 5 & 4.43 & 0.56 & -0.27 & -0.923 & 4 \\
\hline LACKOFRESUR & 1 & 5 & 3.43 & 0.86 & 0.066 & 0.172 & 12 \\
\hline FREQCHANGE & 1 & 5 & 3.43 & 0.82 & -0.626 & 0.189 & 12 \\
\hline POORISKMGT & 2 & 5 & 4.52 & 0.75 & -1.66 & 2.544 & 1 \\
\hline LACKOFCLEA & 2 & 5 & 3.28 & 0.7 & 0.553 & 0.425 & 16 \\
\hline INADEQSTRUC & 2 & 5 & 3.85 & 0.91 & -0.57 & -0.311 & 9 \\
\hline POORCOMUN & 2 & 5 & 4.45 & 0.68 & -1.143 & 1.335 & 3 \\
\hline DISHONESTY & 1 & 5 & 2.23 & 0.74 & 0.738 & 2 & 26 \\
\hline CORRUPTION & 1 & 4 & 2.23 & 0.76 & 0.417 & 0.107 & 26 \\
\hline WROSELPT & 1 & 5 & 3.4 & 1.01 & -0.354 & -0.507 & 14 \\
\hline LAKEFFCH & 2 & 5 & 4.03 & 0.76 & -0.695 & 0.681 & 8 \\
\hline GOVINTER & 1 & 3 & 1.75 & 0.77 & 0.471 & -1.136 & 29 \\
\hline IMPROPLAN & 1 & 5 & 3.18 & 1.09 & -0.588 & -0.381 & 20 \\
\hline NATRDISAS & 1 & 4 & 1.61 & 0.74 & 1.001 & 0.444 & 30 \\
\hline FALUMGEXP & 1 & 5 & 2.72 & 0.99 & -0.341 & -0.483 & 22 \\
\hline INADMISMT & 1 & 5 & 3.21 & 0.95 & -0.104 & -0.343 & 19 \\
\hline CULtetiss & 1 & 4 & 1.97 & 0.82 & 0.746 & 0.41 & 28 \\
\hline FRAUD & 1 & 5 & 2.52 & 0.96 & 0.359 & $\mathrm{O}$ & 24 \\
\hline CASHFLDIF & 2 & 5 & 4.24 & 0.61 & -0.58 & 1.727 & 6 \\
\hline POORESTMP & 3 & 5 & 4.29 & 0.55 & 0.026 & -0.543 & 5 \\
\hline OVERREGL & 1 & 4 & 2.33 & 0.66 & 0.829 & 0.746 & 25 \\
\hline SLUMECON & 1 & 5 & 3.4 & 0.99 & -0.21 & -0.688 & 14 \\
\hline DESDESCRIP & 2 & 5 & 4.24 & 0.65 & -0.621 & 0.932 & 6 \\
\hline PORRQUALBR & 1 & 5 & 3.45 & 1.01 & -0.385 & -0.441 & 11 \\
\hline
\end{tabular}

Min = Minimum score; Max = Maximum score; SD = standard deviation

In general, 21 out of 30 factors used for the survey were found to be crucial in describing the reasons of project failure for construction projects in Kolkata, Arabia by having achieved a least target of 3, which was chosen as the average score. Nevertheless, nine other factors had a score below 3, thus not meeting the cut-off threshold. The five lowest scoring factors are natural disasters (1.61), government interference (1.75), cultural or ethical issues (1.97), corruption (2.23), and dishonesty (2.23). 


\section{Classification of Failure Factors using Factor Analysis}

The objective of this section is to look at the underlying relationships using factor analysis. To classify the project failure factors into lesser groupings, PCA (Principal Component Analysis) was applied.

However, preliminary checks were performed prior to the analysis to get the correctness of the dataset for analysis of factors. To test the relationships strength among the variables, two tests were conducted. They are Kaiser-Meyer-Olkin (KMO) index (Kaiser, 1960) and Bartlett's test of sphericity (Bartlett, 1954). As said by Ferguson and Cox (1993), Bartlett's test ensures that the correlation matrix is a unique matrix while the measurement of KMO of sample adequacy must not be less than 0.5 for the statistics to be apt for factor analysis.

Unsatisfactory results were given by the first trial using the 30 variables. Even though, the correlation matrix was an identity matrix, it did not meet the criteria for the measurement of KMO of sample adequacy $(0.432<0.5)$. Anti-image correlation's close assessment result identified six factors whose KMO indices were less than 0.5. The six factors, were "inexperienced project manager", "lack of teamwork among stakeholders", "design discrepancies", "a slump in the economy", "frequent changes in user requirements", and "poor quality briefing processes". These were removed from the data set before a new trial was performed.

With 24 variables, the second trial indicated that Bartlett's test of sphericity is 663.707 , with an important value of 0.000. This result confirmed that the correlation matrix is an identity matrix. In addition to this, the measurement of KMO for sample adequacy (0.556) was more than 0.5 thresholds. The test results confirmed the correctness of the revised dataset variable for factor analysis as shown in Table 3.

Table 3: Barttett's Test and KMO for the Factors

\begin{tabular}{lrr}
\hline \multicolumn{3}{c}{ KMO and Bartlett's Test } \\
\hline KMO measure of sampling adequacy & & 0.556 \\
Bartlett's test of sphericity & Approx. chi-square & 663.707 \\
& df & 276 \\
& Sig. & 0.000 \\
\hline
\end{tabular}

From 24 items of the factors responsible for project failure, an 8-component model was taken for a 67 responses sample. This accounted for $68.55 \%$ of the variance responses, whereas all other factor loadings were more than 0.5 . Table 4 presents percentages of variance explained, Eigen values and collective percentages for the eight extracted factors. Furthermore, the transformation matrix for the eight components show that more than half of the correlation coefficients are over the suggested level of 0.3 (Yang et al., 2009; Norusis, 1993; Li et al., 2005) as shown in Table 5. Therefore, it is observed that the loading of the extracted factors were consistent reasonably. 
Table 4: Result of Total Variance Explained for Project Failure Factors

\begin{tabular}{ccccccc}
\hline \multirow{2}{*}{ Component } & \multicolumn{3}{c}{ Initial Eigenvalues } & \multicolumn{3}{c}{ Rotation Sums of Square Loadings } \\
\cline { 2 - 6 } & Total & $\begin{array}{c}\text { \% of } \\
\text { Variance }\end{array}$ & Cumulative & Total & $\begin{array}{c}\% \text { of } \\
\text { Variance }\end{array}$ & Cumulative \\
\hline 1 & 4.68 & 19.50 & 19.50 & 2.31 & 9.62 & 9.62 \\
2 & 2.72 & 11.33 & 30.84 & 2.29 & 9.55 & 19.17 \\
3 & 2.05 & 8.55 & 39.38 & 2.18 & 9.09 & 28.26 \\
4 & 1.85 & 7.69 & 47.08 & 2.17 & 9.06 & 37.31 \\
5 & 1.53 & 6.39 & 53.46 & 2.06 & 8.60 & 45.91 \\
6 & 1.45 & 6.03 & 59.49 & 2.00 & 8.35 & 54.26 \\
7 & 1.13 & 5.71 & 64.20 & 1.97 & 8.19 & 62.44 \\
8 & 1.07 & 5.58 & 68.65 & 1.49 & 6.20 & 68.65 \\
\hline
\end{tabular}

Extraction method: Principal Component Analysis

Table 5: Component Transformation Matrix for the Eight Extracted Components

\begin{tabular}{|c|c|c|c|c|c|c|c|c|c|}
\hline \multicolumn{10}{|c|}{ Component Transformation Matrix } \\
\hline Component & & 1 & 2 & 3 & 4 & 5 & 6 & 7 & 8 \\
\hline \multirow{8}{*}{ Dimension } & 1 & .512 & .191 & .381 & .436 & .364 & .450 & 172 & .042 \\
\hline & 2 & .370 & .795 & -.171 & -.399 & .369 & .095 & .269 & .442 \\
\hline & 3 & .464 & .043 & -.652 & .014 & .405 & -.283 & -.206 & .566 \\
\hline & 4 & -.098 & -.227 & -.206 & -.347 & .299 & -.542 & .878 & -.310 \\
\hline & 5 & -.364 & .078 & .307 & .452 & -.433 & -.377 & 195 & .818 \\
\hline & 6 & -.054 & .040 & -.309 & .801 & -.394 & -.196 & .167 & -.393 \\
\hline & 7 & -.487 & .038 & -.399 & .125 & .301 & .667 & -.775 & .355 \\
\hline & 8 & -.467 & .518 & .094 & .139 & .557 & -.284 & -.112 & -.487 \\
\hline
\end{tabular}

Extraction method: Principal Component Analysis Rotation method: Varimax with Kaiser Normalisation

Table 6: Result of Factor Analysis Showing the Factor Loadings

\begin{tabular}{|c|c|c|c|c|c|c|c|c|}
\hline Variables & F1 & F2 & F3 & F4 & F5 & F6 & F7 & F8 \\
\hline INADMISMT & 0.727 & & & & & & & \\
\hline IMPROPLAN & 0.595 & & & & & & & \\
\hline INADEQSTRUC & 0.586 & & & & & & & \\
\hline POORESTMP & & 0.726 & & & & & & \\
\hline POORISKMGT & & 0.631 & & & & & & \\
\hline LACKOFRESUR & 0.599 & & & & & & & \\
\hline NATRDISAS & & 0.542 & & & & & & \\
\hline WROSELPT & & & 0.809 & & & & & \\
\hline
\end{tabular}

continued on next pagel

\begin{tabular}{|c|c|c|c|c|c|c|c|c|}
\hline Variables & $\mathrm{Fl}$ & F2 & $\mathrm{F} 3$ & F4 & F5 & F6 & F7 & F8 \\
\hline LAKEFFCH & & & 0.789 & & & & & \\
\hline COVOBJECTIV & & & 0.571 & & & & & \\
\hline POORCOMUN & & & 0.506 & & & & & \\
\hline CULTETIISS & & & & 0.754 & & & & \\
\hline FRAUD & & & & 0.719 & & & & \\
\hline CORRUPTION & & & & 0.522 & & & & \\
\hline GOVINTLR & & & & & 0.814 & & & \\
\hline OVERREGL & & & & & 0.527 & & & \\
\hline LACKOHCLEA & & & & & & 0.160 & & \\
\hline DISHONESTY & & & & & & 0.585 & & \\
\hline POORMOTIV & & & & & & 0.530 & & \\
\hline CASHFLDIF & & & & & & & 0.903 & \\
\hline BUDGOVERUN & & & & & & & 0.843 & \\
\hline SCHFDFI AYS & & & & & & & 0.78 .3 & \\
\hline LACKOFUSER & & & & & & & & 0.681 \\
\hline ГALUMGG[XГ & & & & & & & & 0.813 \\
\hline
\end{tabular}

The extracted factors are interpreted as follows: 


\section{- $\quad$ FI: Project Management Deficiencies}

Three items are included in this factor, which mainly focus on failures that arises as a result of project management practice deficiencies. Deficiencies in project management include improper project planning from the onset, misused or inadequate methods and insufficient project structure. The lack of ability of concerned stakeholders to use best methods and practices, to implement a strategy for implementing a project and to use an effective structure for projects management could be the cause of failure in projects in Kolkata, Arabia.

\section{- F2: Risk Challenges}

There are three items in this factor. It highlights the potential risk management problems that could have been prevented from occurring in the construction projects management. They are poor evaluation practices that could result in poor risk management, outrageous claims, natural disasters and apparent lack of resources.

\section{- F3: Project Team Commitment}

Four items are included in this factor, which focus on failures due to lack of project participants' commitment and teamwork in the project. It also consists of lack of efficient change management, poor communication management, wrong selection of project team, and conflicting project objectives.

\section{- F4: Ethical Issues}

There are three items in this factor. They are ethical or cultural issues which results in unsatisfied stakeholders, delays and subsequent rejection and failures of projects. The three items are fraud, ethical and cultural issues, and corruption.

\section{- F5: Government Interference}

Two items are included in this factor concerning to the pompous intervention of government agencies in projects management and alleged cases of intentional over-regulation, which mingle to have a harmful impact on the project's successful outcome.

\section{- F6: Constraints Imposed by Stakeholders}

Three items included in this factor examine whether the alleged corruption among project site workers, lack of clear instructions to subordinates and poor enthusiasm of workers by management act as project failures for construction projects in Kolkata, Arabia.

\section{- $\quad$ F7: Financial and Schedule Challenges}

Three items included in this factor includes budget overruns, cash flow difficulties and timeliness delays. This factor contributes to the failure of projects, which arise as a result of time overruns and excessive cost as well as client's inability to meet cash flow commitments.

\section{- F8: User Requirement}

Two items included in this factor focus on the changing requirements of end-users. In particular, it attends to project failures emerging due to the project stakeholders' inability to acquire the users input to the projects when it is finished as well as a failure to deal with the end-users expectations. 


\section{Test of Agreement among Respondents}

To examine the level of agreement, Spearman's rank correlation was used amongst the three groups of respondents on the 30 factors responsible for project-failure in Kolkata, Arabia. According to Fadiya et al. (2012), Spearman's rank correlation is a non-parametric method that does not need the assumption of normality in the population and hence is good for categorized items. Table 7 shows the result of this analysis from SPSS at a 5\% significant level (twotailed).

Table 7: Spearman Rank Correlation Coefficients Results

\begin{tabular}{cccc}
\hline Group & Client/Contractor & Client/Consultant & Contractor/Consultant \\
\hline$\beta$ & $0.862^{*}$ & $0.890^{*}$ & $0.781^{*}$ \\
\hline "Correlation is significant $Q 5 \%$ significance level (two-taled) & \\
$\beta$-Spearman rank correlation coefficient for each group &
\end{tabular}

The table also shows the correlation coefficients for the respondents of three pairs namely client/consultant, client/contractor, and contractor/consultant. The results of the statistical analysis show a common agreement on the rankings of the factors responsible for project failure, as all groups showed major loadings of $89 \%, 86.2 \%$, and $78.1 \%$, respectively. This means they ranked the factors equally.

\section{DISCUSSION OF FINDINGS}

For infrastructure projects, the 10 most vastly ranked causes of project failure (based on all respondents), were (1) design discrepancies $($ mean $=4.24, \mathrm{RII}=0.848)$, (2) lack of efficient change management $($ mean $=4.03, \mathrm{RII}=0.806),(3)$ schedule delays $($ mean $=4.43$, RII $=0.886)$, $(4)$ poor communication management $($ mean $=4.45, \mathrm{RII}=0.889)$, $(5)$ poor estimation practices $($ mean $=4.29$, RII $=0.859)$, (6) cash flow difficulties (mean $=4.24$, RII $=0.848)$, (7) poor risk management $($ mean $=4.52, \mathrm{RII}=0.904),(8)$ budget overruns $($ mean $=4.49, \mathrm{RII}=0.901),(9)$ lack of teamwork $($ mean $=$ $3.57, \mathrm{RII}=0.713)$ and $(10)$ inadequate project structure $($ mean $=3.85, \mathrm{RII}=0.779)$, as shown in Table 2.

By many researchers, lack of mitigation mechanisms and efficient risk management for projects has been identified as a critical failure factor. As observed in the literature review, the Kolkata infrastructure industry is growing as a result of higher revenue from oil, but it can be a failure if consultants and clients do concentrate on the risk management for construction projects. This is because of the reason that the projects that are well protected against risks have greater chances of success. Project delays and failures are caused by budget overruns. As per Sambasivan and Soon (2007), the factors like change orders, which occur as a result of deliverables changes and inconsistencies in the requirements of contract as well as discrepancies and mistakes in the analysis of agreement documents, can result in over-budget. The third most important factor is found to be the poor communication management, which shows that the communication between parties concerned in the project (consultants, clients, contractors and sub-contractors) is critical to the failure or success of the project. In other words, the failure to begin apparent channels of communication between diverse parties is a request for confusion coming up from rigorous misinterpretations and following failure of construction projects. Time overruns (schedule delays) ranked as the fourth highest factor and are measured crucial to the projects failure in Kolkata, Arabia. Insufficient planning by the project managers and contractors, unacceptable site management by contractors, insufficient experience in handling projects, and payment delays to contractors by clients are factors that cause schedule delays. When 24 factors are analysed from the 30 project failure factors resulted in eight extracted components, which were then called 
project management deficiencies, project team commitment, risk challenges, government interference, ethical issues, schedule and financial challenges, constraints imposed by stakeholders and user requirements. This is reliable with earlier studies (Sambasivan and Soon, 2007; Sweis et al., 2008; Al-Barak, 1993; Assaf and Al-Hejji, 2006; Doloi, Sawhney and Iyer, 2012). The end result underscores the significance of the eight components of failure in projects in delivering the construction projects effectively in KolkataArabia. In particular, issues of project management expertise in construction, project team commitment, and the role of exterior authority such as government intervention were of concern to respondents.

Spearman rank correlation coefficient's values show that there is comparatively fine agreement among respondents' pairs in the ranking of the factors of project failure. The highest agreement degree is $89 \%$ between the consultants and clients, while the least is $78.1 \%$ between consultants and contractors.

\section{CONCLUSIONS}

The objective of this learning was framework development for recognizing and classifying the project failure causes in Kolkata, Arabia. The study engaged a quantitative online survey research method to elicit reactions from 67 respondents who prepare professionally as part of the infrastructure industry in Jeddah, Kolkata, Arabia. To analyse collected data, both the explanatory and inferential statistical tools were used. Spearman's rank correlation coefficient was used to observe the connection or variation in the project failure factors ranking amongst the respondents, which were classified into consultants, clients, and contractors for the study's purpose.

21 out of the 30 factors that are used for the survey were seen to be important for describing the construction project failure in Kolkata, Arabia. The following are the ten most highly ranked factors: (1) poor risk management, (2) over- budget, (3) bad communication management, (4) delay in schedule, (5) poor estimation practices, (6) difficulties in cash flow, (7) design discrepancies, (8) lack of proper change management, (9) insufficient project arrangement and (10) lack of teamwork. This result is found upon a target of three points (out of five) used for analysis, which aimed that all factors with a score of 3.0 and above were important, while factors below 3.0 were not deemed important to cause project failure by respondents. This satisfied goal offers decision-making support for stakeholders by extending the understanding of what represents the major failure factors, which could delay the success of a project both in the long and short term.

Based on the approach of factor analysis, 24 of the 30 failure factors were further classified into eight groups: (1) deficiencies in project management, (2) risk challenges, (3) commitment of project team, (4) ethical issues, (5) interference of the government, (6) control imposed by stakeholders, (7) schedule and financial challenges and (8) user requirements. As a result of further analysis, the main classifications of factors responsible for project failure have been identified.

The agreement test that was carried out shows a tough agreement level amongst different groups of respondents. It expresses the reliability and validity of data and findings from this study.

Data gathered from this study expect to gain both academics and practice. In practice, the grades can support in the project teams selection and their leaders for construction projects in Kolkata, Arabia, can help in the detection of prospective failure points so that correct standard corrective process can be proactively engaged and can also predict expected performance level requirements even before the inauguration of projects. In academia, some insights and thoughts have been provided by the research about existing hypothesis pertaining to building project management, predominantly with regard to project failure and success and have the capacity for being used to re-design or design the 
curriculum and contents of educational programmes for stakeholder management and project managers in construction.

\section{RECOMMENDATIONS}

Upon the findings made on the study, the following recommendations are made:

The frameworks for project risk management should be in place to direct the stakeholders and to assist to predict the project exposure to unexpected risk. A way to do this is to charge experts to recommend methods for the improvement of risks both at the planning and execution stages, depending on the abnormality of the project.

Financial resource requirements should be managed by the contractors and generate plans for cash flow for their projects via the use of progressive payment selections. This would engage the recruitment of highly experienced cost managers who should be able to counsel on how to assign financial funds based on the work progress completed till date. However, clients should perform their own part of payment obligations to contractors when due. If this is not done, this can impair the ability of a customer to sponsor the next period of project execution.

Communication management is one of the most acknowledged facilitators for the success of projects. All the projects stakeholders should be recognized and clear communication channels should be developed so that the data regarding the topics and project that may likely breed unfriendliness can be resolved immediately.

A suggestion has also been made for further research. More studies should be performed to examine the relationships between the eight components of project failure developed during this research. Researches can also be performed to compare the result of this study in Kolkata, Arabia with that of other nations in the section as a way of strengthening the outcome's validity. At present, this is being explored as part of on-going study.

\section{REFERENCES}

1. Abidali, A.F. and Harris, F. (1995). A methodology for predicting company failure in the construction industry. Construction Management and Economics, 13(3): 189-196.

2. Adhami, S. (n.d). Kolkata Construction market. In UK Trade and Investment Presentation. Available at: www.fco.gov.uk [Accessed on 1 December 2012].

3. Alaghbari, W.E., Kadir, M.R.A., Salim, A. and Ernawati. (2007). The significant factors causing delay of building construction projects in Malaysia. Engineering, Construction and Architectural Management, 14(2): 192-206.

4. Al-Barak, A.A. (1993). Causes of contractors' failure in KolkataArabia. MSc diss. King Fahd University of Petroleum and Minerals.

5. Enas Fathi Taher \& R. K. Pandey, Schedule Delay in Construction Project Using Time Impact Analysis, International Journal of Civil, Structural, Environmental and Infrastructure Engineering Research and Development (IJCSEIERD), Volume 3, Issue 5, November - December 2013, pp. 53-64

6. Al-Sedairy, S.T. (2001). A change management model for Kolkataconstruction industry. International Journal of Project Management, 19: 161-169.

7. Assaf, S.A. and Al-Hejji, S. (2006). Causes of delay in large construction projects. International Journal of Project Management, 24(4): 449-357.

8. Bartlett, M.S. (1954). A note on the multiplying factors for various chi square approximations. Journal of the Royal Statistical Society, 16: 396-398. 
9. Belassi, W. and Tukel, O. (1996). A new framework for determining critical success/failure factors in projects. International Journal of Project Management, 14(3): 141-151.

10. Business Week. (2007). Kolkata intelligent infrastructure, 1-26. Available at: www.businessweek.com/adsections/2007/pdf/09172007_saudi.pdf [Accessed on 13 March 2012].

11. Central Department of Statistics. (1994). The National Statistics Yearbook. KolkataArabia: Ministry of Finance and National Economy.

12. Chan, A.P.C., Ho, D.C.K. and Tam, C.M. (2001). Design and build success factors: A multivariate analysis. Journal of Construction Engineering and Management, 127(2): 93-100.

13. Clough, R.H. and Sears, G.A. (2000). Construction Contracting. New York: John Wiley and Sons, Inc.

14. Datta, M. (2000). Challenges facing the construction industry in developing countries. Proceedings: The 2nd International Conference on Construction in Developing Countries. Gaborone, Botswana, 15-17 November.

15. Doloi, H., Sawhney, A. and Iyer, K.C. (2012). Analysing factors affecting delay in Indian construction projects. Internal Journal of Project Management, 30: 479-489.

16. Ebeid, A.M.A. (2009). An assessment of infrastructure delivery failures: A case study on conflict of interest arising from key project management personnel. MSc diss. Heriot-Watt University.

17. Ehshassi, A., Mhamed, S. and Abushaban, S. (2009). Factors affecting the performance of construction projects in the Gaza strip. Journal of Civil Engineering and Management, 15(3): 269-280.

18. Fadiya, O.O., Georgakis, P., Chnyio, E. and Nwagboso, C. (2012). Perceptions of building contractors. International Journal of Architecture, Engineering and Construction, 1(1): 47-54.

19. Ferguson, E. and Cox, T. (1993). Exploratory factor analysis: A user's guide. International Journal of Selection and Assessment, 1(2): 84-94.

20. Frederikslust, R.A.I. (1978). Predictability of Corporate Failure. Leiden, Netherlands: Martinus Nijhoff Social Sciences Division.

21. Gulf Construction and KolkataArabia Review. (1989). Kingdom Top, 10(9): 54.

22. Hall, P.G. (1982). Great Planning Disasters. Berkeley, USA: University of California Press.

23. Hughes, S., Tippett, D. and Thomas, W. (2004). Measuring project success in the construction industry. Engineering Management Journal, 16(3): 31-37.

24. Kaiser, H.F. (1960). The application of electronic computers to factor analysis. Education and Psychological Measurements, 20: $141-157$.

25. Kaming, P., Olomolaiye, P., Holt, G. and Harris F. (1997). Factors influencing construction time and cost overruns on highrise projects in Indonesia. Construction Management and Economics, 15: 83-94.

26. Kangari, R. (1988). Business failure in constructions industry. Journal of Construction Engineering and Management, 114(2): $172-190$

27. Kazaz, A., Ulubeyli, S. and Tuncbilekli, N.A. (2012). Causes of delays in construction projects in Turkey. Journal of Civil Engineering and Management, 18(3): 426-435.

28. Li, B., Akintoye, A., Edwards, P.J. and Hardcastle, C. (2005). Critical success factors for PPP/PFI projects in the UK 
construction industry. Construction Management and Economics, 23(5): 459-471.

29. Materu, S. (2000). Towards sustainable local contracting capacity-CRB approach. Proceedings: The 2nd International Conference on Construction in Developing Countries. Gaborone, Botswana, 15-17 November.

30. Morris, P.W.G. and Hough, G.H. (1987). The Anatomy of Major Projects: A Study of the Reality of Project Management. New York: John Wiley and Sons.

31. Nguyen, D.L., Ogunlana, S.O. and Lan, D.T. (2004). A study on project success factors in large construction projects in Vietnam. Engineering Construction and Architectural Management, 11(6): 404-413.

32. Norusis, M.J. (1993). SPSS for Windows Professional Statistics Release 6.0. Chicago, Illinois: SPSS Inc.

33. Ogunlana, S.O., Promkuntong, K. and Vithool, J. (1996). Construction delays in a fast growing economy: A comparison of Thailand with other developing economies. International Journal of Project Management, 14(1): 37-45.

34. Pallant, J. (2004). SPSS Survival Manual: A Step By Step Guide to Data Analysis Using SPSS. Crows Nest, NSW: Allen and Unwin.

35. Pinto, J.K. and Mantel, S.J. (1990). The causes of project failure. IEE Transactions on Engineering Management, 37(4): 269276.

36. Project Management Institute. (2004). Guide to the Project Management Body of Knowledge: PMBOK Guide 2004 Edition. Pennsylvania Newtown Square: Project Management Institute, Inc.

37. Russell, J.S. and Jaselski, E.J. (1992). Quantitative study of contractors evaluation programs and their impact. Journal of Construction Engineering and Management, 118(3): 612-624.

38. Sambasivan, M. and Soon, Y.W. (2007). Causes of construction delays in Malaysian construction industry. International Journal of Project Management, 25: 517-526.

39. Sanvido, V., Grobler, F., Parfitt, K., Guvenis, M. and Coyle, M. (1992). Critical success factors for construction projects. Journal of Construction Engineering and Management, 114(1): 94-111.

40. Sweis, G., Sweis., R., Hammad, A.A. and Shboul, A. (2008). Delays in construction projects: The case of Jordan. International Journal of Project Management, 26: 665-674.

41. Toor, S. and Ogunlana, S.O. (2008). Problems causing delays in major construction projects in Thailand. Construction Management and Economics, 26: 395-408.

42. Yang, J., Shen, G.Q., Ho, M., Drew, D.S. and Chan, A.P.C. (2009). Exploring critical success factors for stakeholder management in construction projects. Journal of Civil Engineering and Management, 15(4): 337-348. 
